\title{
Research on Water Conservancy Project Construction and Operation Management based on Cost Management
}

\author{
Liu Xingwen ${ }^{1}$ \\ ${ }^{1}$ Gansu Provincial Yintao Project Construction Administration, Lanzhou, Gansu 730000
}

\begin{abstract}
With the development and progress of the economy and society, the management level of my country's construction projects has also been greatly improved, especially in the construction of water conservancy projects, and the cost management in the process has made significant progress; the water conservancy industry is in order to improve the market of enterprises. Competitiveness, to increase the market share of the company, it is necessary to improve the management level of the company in an all-round way, and maximize the economic benefits of the company.In order to improve the efficiency of cost management and operation management in the construction of water conservancy projects, this study conducts a theoretical analysis of the project cost management, taking the reinforcement treatment of the expansion joints of the culverts of the main canal project of the first phase of the water diversion water supply as a research case, and analyzes the expansion joints of the culverts of the project. This paper conducts a comprehensive investigation, proposes a repair plan using chemical bonding with external TPO waterstop and PTN petroleum asphalt polyurethane joint material, and makes a detailed investment estimate for project implementation. The results show that the bonding externally attached TPO waterstop and PTN petroleum asphalt polyurethane joint materials can meet the needs of this design for strengthening and strengthening the waterstop of the expansion joint of the culvert. The total static investment of construction engineering, mechanical and electrical equipment and installation engineering, construction temporary engineering, independent costs and basic reserve costs is $4,585,800$ yuan, of which the total cost of underdrain expansion joint treatment is 3,594,600 yuan, which is in line with expectations, indicating that the water conservancy project of this design .The cost management plan is feasible.
\end{abstract}

\section{Introduction}

With the development of the national economy and the continuous deepening of reforms, development and water conservancy project construction, as one of the infrastructure projects of the national economy, are also booming. [1]. During the "13th Five-Year Plan" period, my country has planned more than 170 large-scale mathematical and physical engineering constructions. Like other construction projects, water conservancy projects need to invest a lot of money in their implementation. The goal of all construction projects is to reduce investment and obtain greater Benefits, watersaving construction projects are no exception. In the investment of water conservancy projects, how to rationally use the limited funds to construct the project and obtain the greatest benefits has become an important research topic [2].

As an infrastructure, investment in water conservancy construction projects has the characteristics of long capital occupation time and long later development time, which determines that the cost management of construction projects should take into account all the costs of the entire project [3]. There are still problems in the management information system of water conservancy projects: First, the control of domestic water resources investment is still in the bidding stage and project implementation stage, but the investment decision and management cost are ignored in the design stage [4]. Secondly, every stage of cost management and control of water conservancy projects is not ideal, so the design of cost management projects is not perfect [5]. Finally, due to different starting interests, each stage of the project is independent of each other, making the investment situation very easy to get out of control, and the cost management of water conservancy construction projects cannot be put into action [6].

Based on this, this research takes the reinforcement treatment of the expansion joints of the concealed canal in the main main canal project of the first phase of the water diversion water supply as an example, designs the expansion plan of the expansion joints of the concealed canal, and conducts detailed cost management of the project, so as to manage and develop the intelligent operation of the water conservancy project. Provide a realistic basis. 


\section{Method}

\subsection{Project cost management system in water conservancy project construction}

Water conservancy project construction is a social production activity, which has the characteristics of fixed construction site, long construction period, large product area and large resource occupation [7]. The main objects of project cost management are suppliers and investors. The project is the object, and the core content is to determine reasonable project costs and effective cost control methods. The goal is to increase investment efficiency and use advanced and scientific management methods to carry out engineering projects. Management [8]. The cost management process of water conservancy project construction is shown in Figure 1 below:



Figure 1 Water conservancy project construction cost management

First, determine the investment stage. The rationality of project cost is the prerequisite for the accuracy of project decision-making, and reasonable estimation and calculation of project cost are required.

Second, the planning stage. The work of the planning stage is to show the future water conservancy construction projects in advance on the drawings, which is a critical period for the formation of product value.

Third, the bidding stage. Public bidding is a method widely used in water-saving construction projects, with a high degree of transparency and equal opportunities [9]. National and local key water conservancy projects, as well as all publicly funded projects, are subject to public bidding.

Fourth, the project implementation stage. This is the largest stage of capital investment. The construction unit should pay attention to management efficiency and deal with changes and complaints reasonably.

Fifth, the completion stage. It is the main basis for the employer and the contractor to settle the project price, and it is also the final key link for the employer to control the project cost [10]. The construction unit must strengthen its auditing capabilities, allocate sufficient personnel, and strictly control the auditing work.

\subsection{Troubleshooting of water conservancy project construction}

In this study, the Dayingliang concealed channel of the main main canal of Gansu Province is taken as an example.
In order to prevent the occurrence of major accidents of channel subsidence caused by the leakage of water in the dayingliang culvert of the main main canal of Tao, Gansu Province Yintao Construction Administration has organized a large number of manpower to divert the channel. A comprehensive investigation has been carried out on the main main canal project of Tao Phase I. According to the inspection results of the main main canal, there are cracks in the expansion joints of part of the main canal. The specific directions are as follows:

The Yangyinxia culvert has cracks at the expansion joints of station number $86+469.08$, with a width of $3 \mathrm{~mm}$; there are cracks at the expansion joints of station No. $86+479.08$, with a width of $1 \mathrm{~mm}$; and there are cracks on both sides of the expansion joints at station No. $86+518.83$, with a width of $4 \mathrm{~mm}$. As shown in Figure 2 below:

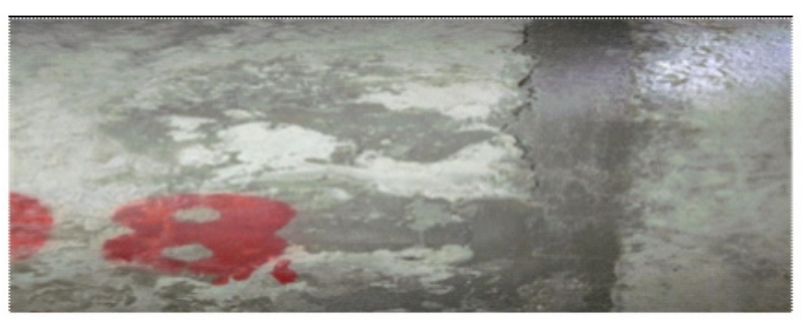

7 Tinyangxia culvert, Stake $86+469.08$

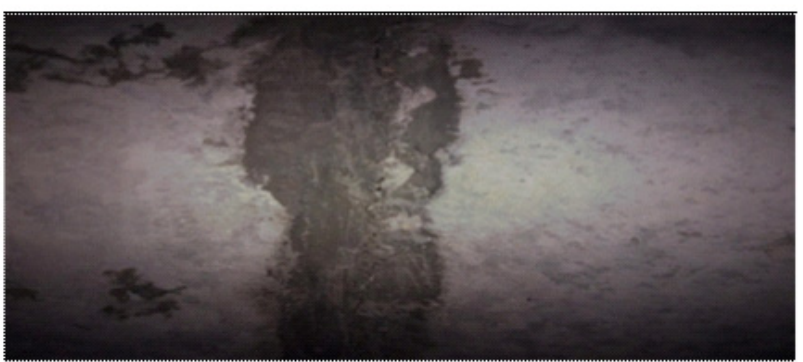

7 "Tinyangxia culvert, Stake $86+479.08$

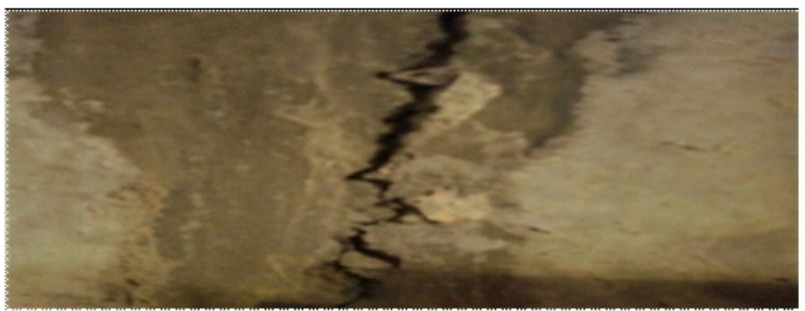

7 \#Yinyangxia culvert, Stake $86+518.83$

Figure 2 Cracks of expansion joints in Yangyinxia culvert

The expansion joints of Hejiacha concealed canal pile No. $87+762.02$ are squeezed by concrete and there are cracks, as shown in Figure 3 below: 


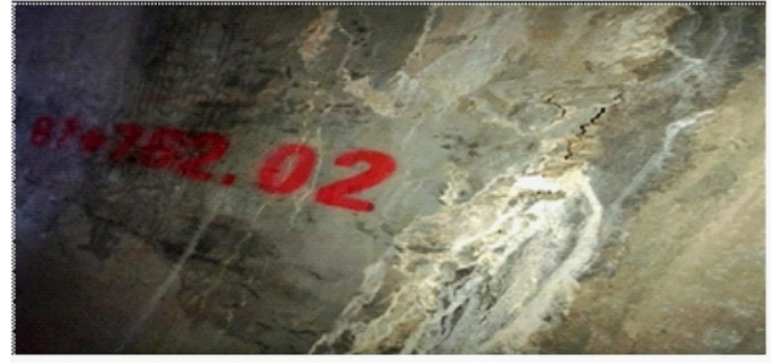

$10^{*}$ Underdrain, Stake $87+762.02$

Figure 3 Cracks in expansion joints of Hejiacha culvert

There are cracks at the expansion joints of Wulongchuan Underdrain Stake No. 90+325.16, with a width of $1 \mathrm{~mm}$. The expansion joints of Wulongchuan culvert at stake $90+455.16$ have concrete skin peeling off; at the expansion joints of stake $90+495.16$, the concrete is squeezed and there are cracks. As shown in Figure 4 below:

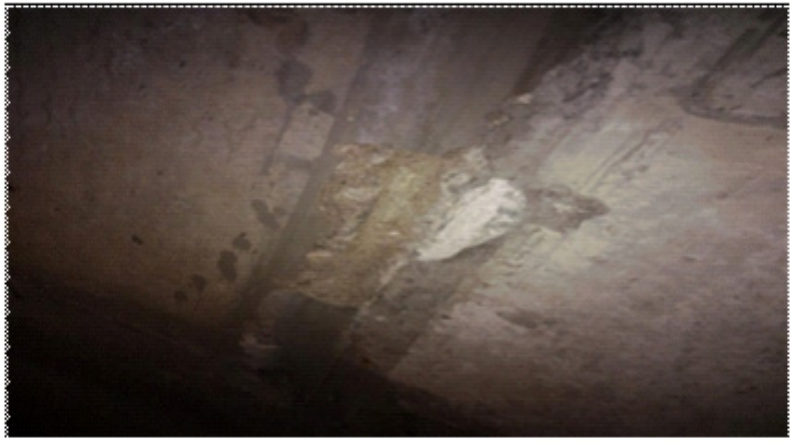



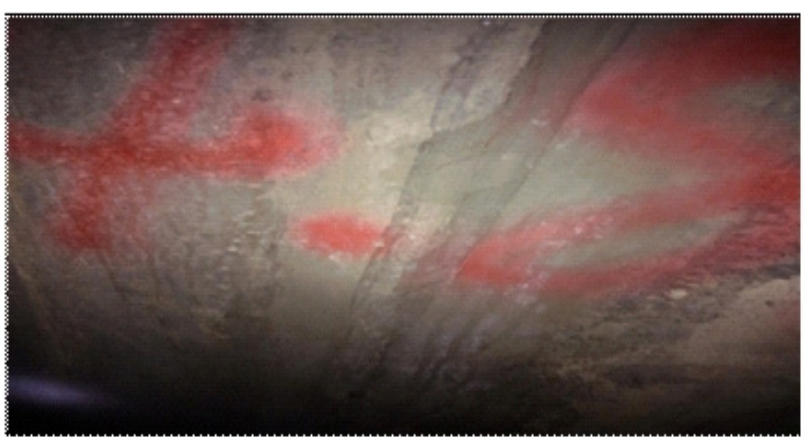

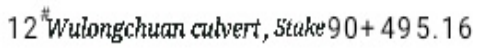

Figure 4 Cracks in expansion joints of Wulongchuan culvert

Underdrain reinforcement scheme

In order to prevent the recurrence of accidents caused by the leakage of water in the culvert in the Dayingliang section of the main main canal, the treatment plan of the main culvert is to reinforce the expansion joints of the culvert in the middle and high collapsible loess foundation to prevent the water and the outside of the culvert. Seepage occurs.

First of all, according to the geological record, the treatment range and length statistics of the expansion joints of the high collapsible loess foundation culvert in the main main canal project of the first phase of the Tao water supply project designed this time are shown in Table 1:

Table 1 Statistics on the treatment length of the expansion joints of the high collapsible loess foundation culvert in the main canal project of the first phase of the Tao water supply

\begin{tabular}{|c|c|c|c|c|c|c|c|c|c|}
\hline $\begin{array}{c}\text { Serial } \\
\text { number }\end{array}$ & $\begin{array}{c}\text { Underdrain name and } \\
\text { number }\end{array}$ & Start and end stake & $\begin{array}{l}\text { Distance } \\
\quad(\mathrm{m})\end{array}$ & Vertical slope & $\begin{array}{l}\text { Underdrain } \\
\text { form }\end{array}$ & $\begin{array}{c}\text { Underdrain } \\
\text { width } \times \text { heig } \\
\text { ht }(\mathrm{m})\end{array}$ & $\begin{array}{l}\text { Single length of } \\
\text { processing } \\
\text { expansion joint } \\
\text { (m) }\end{array}$ & 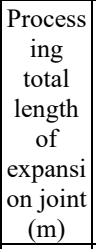 & $\begin{array}{l}\text { Underdrain } \\
\text { treatment range }\end{array}$ \\
\hline 1 & Yangyinxia culvert & $\begin{array}{c}86+129.32 \sim \\
86+549.95 \\
\end{array}$ & 420.63 & $1 / 2000$ & $\begin{array}{c}\text { Arc bottom } \\
\text { rectangle }\end{array}$ & $4.45 \times 4.04$ & 12.53 & 538.8 & $\begin{array}{c}\text { Side wall floor } \\
\text { treatment }\end{array}$ \\
\hline 2 & Hejiacha culvert & $\begin{array}{c}87+656.33 \sim 87+ \\
878.71 \\
\end{array}$ & 222.38 & $1 / 1235.4$ & $\begin{array}{l}\text { Horseshoe- } \\
\text { like }\end{array}$ & $4.26 \times 4.42$ & 14.256 & 356.4 & $\begin{array}{c}\text { Full section } \\
\text { treatment }\end{array}$ \\
\hline 3 & Xujiahe culvert & $\begin{array}{c}88+834.95 \sim \\
88+885.91\end{array}$ & 50.96 & $1 / 1500$ & $\begin{array}{l}\text { Horseshoe- } \\
\text { like }\end{array}$ & $4.26 \times 4.42$ & 14.256 & 71.3 & $\begin{array}{c}\text { Full section } \\
\text { treatment }\end{array}$ \\
\hline 4 & Wulongchuan culvert & $\begin{array}{c}88+880.76 \sim \\
89+930.0 \\
\end{array}$ & 1049.24 & $1 / 2000$ & $\begin{array}{c}\text { Arc bottom } \\
\text { rectangle }\end{array}$ & $4.45 \times 4.04$ & 12.54 & 1316.7 & $\begin{array}{c}\text { Side wall floor } \\
\text { treatment }\end{array}$ \\
\hline 5 & Wulongchuan culvert & $\begin{array}{c}89+930.00 \sim \\
90+583.3\end{array}$ & 653.3 & $1 / 1500$ & $\begin{array}{l}\text { Horseshoe- } \\
\text { like }\end{array}$ & $4.26 \times 4.42$ & 14.256 & 940.9 & $\begin{array}{c}\text { Full section } \\
\text { treatment }\end{array}$ \\
\hline
\end{tabular}




\begin{tabular}{|c|c|c|c|c|c|c|c|c|c|}
\hline 6 & $\begin{array}{c}\text { Qinggang Cha concealed } \\
\text { canal }\end{array}$ & $\begin{array}{c}\text { alter } \\
0+10.87 \sim 92+918.8 \\
\end{array}$ & 379.71 & $1 / 1500$ & \begin{tabular}{|c|}
$\begin{array}{c}\text { Horseshoe- } \\
\text { like }\end{array}$ \\
\end{tabular} & $4.26 \times 4.42$ & 14.256 & 427.7 & $\begin{array}{c}\text { Full section } \\
\text { treatment }\end{array}$ \\
\hline 7 & $\begin{array}{l}\text { Heishuigou culvert } \\
\text { (front) }\end{array}$ & $\begin{array}{c}93+937.0 \sim \\
\text { alter } 0+245.24\end{array}$ & 265.24 & $1 / 1500$ & $\begin{array}{c}\text { Horseshoe- } \\
\text { like }\end{array}$ & $4.26 \times 4.42$ & 14.256 & 399.2 & $\begin{array}{c}\text { Full section } \\
\text { treatment }\end{array}$ \\
\hline 8 & Heishuigou culvert (rear) & $\begin{array}{c}\text { alter } \\
0+364.09 \sim \\
94+703.86 \\
\end{array}$ & 233.41 & $1 / 1500$ & $\begin{array}{c}\text { Horseshoe- } \\
\text { like }\end{array}$ & $4.26 \times 4.42$ & 14.256 & 356.4 & $\begin{array}{l}\text { Full section } \\
\text { treatment }\end{array}$ \\
\hline 9 & Heyegou culvert & $\begin{array}{l}95+524.0 \sim \\
95+852.67\end{array}$ & 328 & $1 / 1500$ & $\begin{array}{c}\text { Horseshoe- } \\
\text { like }\end{array}$ & $4.26 \times 4.42$ & 14.256 & 484.7 & $\begin{array}{c}\text { Full section } \\
\text { treatment }\end{array}$ \\
\hline 10 & Xiangquan Underdrain & $\begin{array}{c}95+852.67 \sim \\
97+570.0 \\
\end{array}$ & 1717.33 & $1 / 2000$ & $\begin{array}{c}\text { Arc bottom } \\
\text { rectangle }\end{array}$ & $4.45 \times 4.04$ & 12.54 & 2156.9 & $\begin{array}{c}\text { Side wall floor } \\
\text { treatment }\end{array}$ \\
\hline 11 & Zhonghe culvert & $\begin{array}{c}97+570.00 \sim \\
97+948.0 \\
\end{array}$ & 378 & $1 / 1500$ & \begin{tabular}{|c|}
$\begin{array}{c}\text { Horseshoe- } \\
\text { like }\end{array}$ \\
\end{tabular} & $4.26 \times 4.42$ & 14.256 & 556.0 & $\begin{array}{c}\text { Full section } \\
\text { treatment }\end{array}$ \\
\hline 12 & Shuichagou culvert & $99+193 \sim 99+439.8$ & 246.8 & $1 / 1500$ & $\begin{array}{c}\text { Horseshoe- } \\
\text { like }\end{array}$ & $4.26 \times 4.42$ & 14.256 & 370.7 & $\begin{array}{l}\text { Full section } \\
\text { treatment }\end{array}$ \\
\hline 13 & Jiaojiawan culvert & $\begin{array}{c}100+395.3 \sim \\
101+672.5 \\
\end{array}$ & 1277.2 & $1 / 1617$ & $\begin{array}{c}\text { Arc bottom } \\
\text { rectangle }\end{array}$ & $4.8 \times 3.95$ & 12.8 & 1651.2 & $\begin{array}{c}\text { Side wall floor } \\
\text { treatment }\end{array}$ \\
\hline 14 & Maliangou culvert & $\begin{array}{c}101+672.5 \sim \\
101+743.0\end{array}$ & 70.5 & $1 / 1000$ & $\begin{array}{c}\text { Horseshoe- } \\
\text { like }\end{array}$ & $3.8 \times 3.89$ & 12.693 & 101.5 & $\begin{array}{c}\text { Full section } \\
\text { treatment }\end{array}$ \\
\hline 15 & Mahe culvert & $\begin{array}{c}106+504.99 \sim \\
106+551.63\end{array}$ & 46.64 & $1 / 1000$ & $\begin{array}{c}\text { Horseshoe- } \\
\text { like }\end{array}$ & $3.8 \times 3.89$ & 12.693 & 76.2 & $\begin{array}{c}\text { Full section } \\
\text { treatment }\end{array}$ \\
\hline 16 & $\begin{array}{l}\text { 2\#Culvert behind the } \\
\text { sluice }\end{array}$ & $\begin{array}{c}108+921.63 \sim \\
109+027.95 \\
\end{array}$ & 106.32 & $1 / 3000$ & $\begin{array}{c}\text { Arc bottom } \\
\text { rectangle }\end{array}$ & $4.8 \times 3.95$ & 13.5 & 162.0 & $\begin{array}{c}\text { Side wall floor } \\
\text { treatment }\end{array}$ \\
\hline \multicolumn{3}{|c|}{ total } & 7445.66 & & & & & 9966.44 & \\
\hline
\end{tabular}

Second, determine the repair material for the expansion joint. In view of the short water stoppage time of the culvert of the main diversion channel, the need for rapid repair of expansion joints, and the unfavorable conditions of the temperature difference between day and night in the northwest and the extreme temperature difference between winter and summer, the waterproof and sealing treatment materials for culvert expansion joints should be durable Humid environment, suitable for humid environment construction, quick and easy construction, long-term exposure to ultraviolet rays and high and low temperature environments in winter and summer, large deformation performance, acid and alkali corrosion resistance, frost heave resistance, aging resistance, excellent mechanical properties, and bondable base It has a wide range of materials, simple surface treatment, non-toxic, environmentally friendly, nonpolluting, comprehensive technical performance, and the principles of being able to meet drinking water standards. Refer to the successful practice of waterproofing, repairing and treatment of water diversion and discharge structures of various water conservancy and hydropower projects. Based on the comparative analysis of a large number of materials that are currently widely used and mature in technology, this design choice determines the use of chemically bonded externally attached TPO waterstop (English name Sikadur-Combiflex ${ }^{\circledR}$ ) and PTN petroleum asphalt polyurethane joint material for repair and protection. Comparison, the performance comparison between the two is shown in Table 2 below:

Table 2 Repair materials and methods of use for expansion joints in the culvert of the main diversion canal

\begin{tabular}{|c|c|c|}
\hline Repair material & Main performance & Instructions \\
\hline $\begin{array}{c}\text { Chemically bonded externally attached } \\
\text { TPO waterstop }\end{array}$ & $\begin{array}{l}\text { Good processing performance and } \\
\text { mechanical properties, weather } \\
\text { resistance, low temperature flexibility, } \\
\text { weldability, sealing and waterproofing. It } \\
\text { can also be constructed on a damp and } \\
\text { water-free base surface without affecting } \\
\text { the bonding effect. }\end{array}$ & $\begin{array}{l}\text { The waterstop is drilled along the axis } \\
\text { of the lining with a reinforcement hole } \\
\text { every } 0.5-1 \mathrm{~cm} \text {, and the finished steel } \\
\text { bar is inserted through the stopper } \\
\text { template. The inner side clamps half of } \\
\text { the waterstop, and the other half of the } \\
\text { waterstop is flat against the stopper. } \\
\text { On the slab, wait for the concrete to } \\
\text { solidify before removing the baffle, } \\
\text { then straighten the waterstop, and then } \\
\text { bend the steel bar to clamp the } \\
\text { waterstop. }\end{array}$ \\
\hline $\begin{array}{l}\text { PTN Petroleum bitumen polyurethane } \\
\text { joint material }\end{array}$ & $\begin{array}{l}\text { High bonding strength and elongation, } \\
\text { good temperature resistance, low } \\
\text { density, water pressure resistance, aging } \\
\text { resistance, frost heave resistance, no } \\
\text { heating and cold construction, simple } \\
\text { and quick construction process, } \\
\text { environmental protection, non-toxic and } \\
\text { non-polluting, high cost performance, } \\
\text { adaptability and bonding and sealing It } \\
\text { has excellent anti-seepage and water- } \\
\text { stop performance, which can enhance }\end{array}$ & $\begin{array}{l}\text { The circumferential expansion joints } \\
\text { between the culverts are kept intact, } \\
\text { and there are rubber waterstops at the } \\
\text { bottom of the expansion joints on the } \\
\text { water-incoming side. All kinds of } \\
\text { caulking materials in the rubber- } \\
\text { stopping waterstops are completely } \\
\text { removed, and the canal surface is } \\
\text { treated. After that, the PTN joints are } \\
\text { filled with impermeable material } \\
\text { densely across the entire section. The }\end{array}$ \\
\hline
\end{tabular}






Finally, the construction method. Use M7.5 cement mortar at the entrance of each culvert to build a 95\# clay red brick wall to block water, the wall height is $2 \mathrm{~m}$, and the outer side of the wall is plastered with cement mortar (according to the culvert layout, 16 brick walls need to be built); Drain stagnant water, clear silt and other operations; wait for the inside of the culvert to dry before proceeding to strengthen the treatment of expansion joints.

Table 3 Principles and basis of project cost management

\subsection{Management basis and investment budget of project cost}

First of all, the principles and basis for cost management of underdrain expansion joints under the main canal are shown in Table 3 below:

\begin{tabular}{|c|l|}
\hline Different dimensions & main content \\
\hline Compilation principle & "Gansu Province Water Conservancy and Hydropower Engineering Design Estimates \\
& (Estimation) Compilation Regulations" issued by "Gan Shui Gui Ji Fa [2013] No. 1", \\
& and "Gan Shui Gui Ji Fa (2016) No. 260" issued in the "Gan Shui Gui Ji Fa (2016) No. \\
& 260" issued by "Gan Shui Gui Ji Fa (2016) No. 260" Measures for the Adjustment of \\
& Value-Added Valuation Basis" and the "Notice of the Gansu Provincial Department of \\
& Water Resources on Adjusting the Valuation Basis of Value-Added Tax Rates for Water \\
& Conservancy Projects" on May 5, 2019. \\
\hline Quota basis & "Gansu Province Water Conservancy and Hydropower Engineering Design Estimates \\
& (Estimation) Compilation Regulations" issued by "Gan Shui Gui Ji Fa [2013] No. 1", \\
& and "Gan Shui Gui Ji Fa (2016) No. 260" issued in the "Gan Shui Gui Ji Fa (2016) No. \\
& 260" issued by "Gan Shui Gui Ji Fa (2016) No. 260" Measures for the Adjustment of \\
& Value-Added Valuation Basis" and the "Notice of the Gansu Provincial Department of \\
& Water Resources on Adjusting the Valuation Basis of Value-Added Tax Rates for Water \\
& Conservancy Projects" on May 5, 2019.
\end{tabular}

Secondly, the estimation method of the segment project investment estimation is shown in Table 4 below: Table 4 Methods of budget estimates for segmented projects

\begin{tabular}{|c|l|}
\hline Project type & \multicolumn{1}{|c|}{ Investment budget method } \\
\hline Construction works & $\begin{array}{l}\text { The project quantity is calculated by multiplying the project unit price. The project unit } \\
\text { price includes direct costs, indirect costs, profits, taxes, and expansion costs. The related } \\
\text { rates are direct engineering costs are calculated according to the corresponding fixed } \\
\text { amount of the construction method, and construction engineering measures costs are } \\
\text { calculated at } 4.5 \% \text { of the direct engineering costs. Indirect costs are calculated based on } \\
\text { small projects, of which earthwork accounts for 13\%, stone works } 16 \% \text { and concrete } \\
\text { works } 60 \% \text {; profit is calculated at } 7 \% \text {; tax: calculated at } 9 \% \text {; expansion fee: required } \\
\text { when calculating the unit price using a budget quota Expand by 5\%. }\end{array}$ \\
\hline Temporary construction works & $\begin{array}{l}\text { Building construction projects under construction are calculated based on the unit cost } \\
\text { index, and other temporary construction projects are calculated based on } 2.1 \% \text { of the } \\
\text { investment in the first to fourth parts of the construction and installation projects. }\end{array}$ \\
\hline Preparation costs & $\begin{array}{l}\text { Calculate survey and design fees, engineering construction supervision fees, bidding } \\
\text { agency fees and engineering insurance fees. }\end{array}$ \\
\hline $\begin{array}{l}\text { Calculated based on 5\% of the total investment of the five parts of construction } \\
\text { engineering, mechanical and electrical equipment and installation engineering, metal } \\
\text { structure equipment and installation engineering, construction temporary engineering } \\
\text { and independent costs. }\end{array}$ \\
\hline
\end{tabular}

Finally, the original price of the main materials adopts the tax-excluded price of the "Gansu Province Project Cost Information" in the third quarter of 2020 in Anding District. The cost of construction machinery is calculated in accordance with the "Gansu Province Water Conservancy and Hydropower Engineering Construction Machinery Cost Quota" issued by Ganshui Regulation [2013] No. 1 Document 0.41. In accordance with the "Gan
Shui Gui Ji Fa (2016) No. 260 No. 7" the "Gansu Province Water Conservancy Project Business Tax Reform Levy Value-added Valuation Basis Adjustment Measures" and May 5, 2019, "Gansu Provincial Water Resources Department's adjustment of water conservancy project pricing basis value-added tax The depreciation expenses in the cost of construction machinery table hours specified in the "Notice of Tax Rates" are divided by the 1.13 
adjustment factor, repair and replacement equipment costs are divided by the 1.09 adjustment factor, and the installation and disassembly costs are not adjusted.

\section{Results and discussion}

\subsection{Comparison of repair and protection}

\section{schemes and use results of chemically bonded externally attached TPO waterstop and PTN petroleum asphalt polyurethane joint materials}

As shown in Table 5 below, the joint materials of bonded external TPO waterstop and PTN petroleum asphalt polyurethane can meet the needs of this design to strengthen the strong chemical culvert expansion joints and meet the requirements of the construction period.

\begin{tabular}{|c|l|}
\hline \multicolumn{1}{|c|}{ Repair material } & \multicolumn{1}{|c|}{ Repair result } \\
\hline Adhesive external TPO waterstop & $\begin{array}{l}\text { The price of } 15 \mathrm{~cm} \text { chemically bonded externally attached TPO waterstop } \\
\text { is } 334.73 \text { yuan per linear meter. A construction team normally constructs } \\
\text { about } 300 \mathrm{~m} \text { a day. }\end{array}$ \\
\hline PTN petroleum asphalt polyurethane joint material & $\begin{array}{l}\text { The design strength is higher than M20, the compressive strength is more } \\
\text { than } 5.0 \mathrm{MPa}, \text { the tensile strength is more than } 1.0 \mathrm{MPa}, \text { the water } \\
\text { absorption is less than } 0.1 \% \text {, the permeability coefficient is less than } \\
0.236 \times 10-9 \mathrm{~cm} / \mathrm{s}, \text { and the frost resistance grade is F200. The price per } \\
\text { linear meter is } 337.69 \text { yuan, and a construction team normally constructs } \\
\text { about } 160 \mathrm{~m} \text { a day. }\end{array}$ \\
\hline
\end{tabular}

\subsection{Estimated results of the implementation plan for the reinforcement treatment of the expansion joints of the culvert}

(1) The total project budget estimates and general budget estimates are shown in the following Tables 6 and 7. The static total investment for construction engineering, mechanical and electrical equipment and installation engineering, construction temporary engineering, independent costs and basic reserve costs is 4,585,800 yuan.

Table 6 Summary of project budget estimates

\begin{tabular}{|c|c|c|c|c|c|c|}
\hline $\begin{array}{c}\text { Serial } \\
\text { number }\end{array}$ & Project or cost name & $\begin{array}{c}\text { Construction cost } \\
\text { (ten thousand yuan) }\end{array}$ & $\begin{array}{c}\text { Equipment purchase } \\
\text { cost (ten thousand } \\
\text { yuan) }\end{array}$ & $\begin{array}{l}\text { Independent cost } \\
\text { (ten thousand } \\
\text { yuan) }\end{array}$ & $\begin{array}{c}\text { Total (ten } \\
\text { thousand yuan) }\end{array}$ & \begin{tabular}{|c|} 
Account for \\
one to five \\
parts of \\
investment \\
$(\%)$ \\
\end{tabular} \\
\hline \multirow[t]{2}{*}{ I } & Engineering part & & & & 458.58 & \\
\hline & Part 1 Construction Project & 359.46 & & & 359.46 & 82.31 \\
\hline & & & & & & \\
\hline & & & & & & \\
\hline & & & & & & \\
\hline & $\begin{array}{c}\text { Part II Mechanical and Electrical } \\
\text { Equipment and Installation Engineering }\end{array}$ & & & & 0.00 & \\
\hline & $\begin{array}{l}\text { Part III Metal Structure Equipment and } \\
\text { Installation Engineering }\end{array}$ & & & & 0.00 & \\
\hline & Part IV Temporary Construction Works & 16.97 & & & 16.97 & 3.89 \\
\hline & Part V Independent Expenses & & & 60.31 & 60.31 & 13.81 \\
\hline & Total investment of one to five parts & 376.43 & & 60.31 & 436.74 & 100.00 \\
\hline & Basic reserve & & & & 21.84 & 5.00 \\
\hline & Static total investment & & & & 458.58 & \\
\hline
\end{tabular}


Table 7 Total budget estimate

\begin{tabular}{|c|c|c|c|c|c|c|}
\hline $\begin{array}{c}\text { Serial } \\
\text { number }\end{array}$ & Project or cost name & $\begin{array}{c}\text { Construction cost } \\
\text { (ten thousand yuan) }\end{array}$ & $\begin{array}{l}\text { Equipment purchase } \\
\text { cost (ten thousand } \\
\text { yuan) }\end{array}$ & $\begin{array}{c}\text { Independent } \\
\text { cost(ten thousand } \\
\text { yuan) }\end{array}$ & $\begin{array}{c}\text { Total (ten } \\
\text { thousand yuan) }\end{array}$ & $\begin{array}{c}\text { Account for } \\
\text { one to five } \\
\text { parts of } \\
\text { investment } \\
(\%)\end{array}$ \\
\hline \multirow[t]{2}{*}{ I } & Engineering part & & & & 458.58 & \\
\hline & Part I Construction Project & 359.46 & & & 359.46 & 82.31 \\
\hline \multirow[t]{4}{*}{ One } & Main Canal Project & 359.46 & & & 359.46 & \\
\hline & $\begin{array}{c}\text { Part II Mechanical and Electrical } \\
\text { Equipment and Installation Engineering }\end{array}$ & & & & 0.00 & \\
\hline & $\begin{array}{l}\text { Part III Metal Structure Equipment and } \\
\text { Installation Engineering }\end{array}$ & & & & 0.00 & \\
\hline & Part IV Temporary Construction Works & 16.97 & & & 16.97 & 3.89 \\
\hline One & Construction house construction project & 9.23 & & & 9.23 & \\
\hline \multirow[t]{2}{*}{ Two } & Other temporary construction works & 7.74 & & & 7.74 & \\
\hline & Part V Independent Expenses & & & 60.31 & 60.31 & 13.81 \\
\hline One & Survey and design fee & & & 40.72 & 40.72 & \\
\hline Two & Tender agency fee & & & 3.76 & 3.76 & \\
\hline Three & Project construction supervision fee & & & 14.14 & 14.14 & \\
\hline \multirow[t]{4}{*}{ Four } & Other & & & 1.69 & 1.69 & \\
\hline & Total investment of one to five parts & 376.43 & & 60.31 & 436.74 & 100.00 \\
\hline & Basic reserve & & & & 21.84 & 5.00 \\
\hline & Static total investment & & & & 458.58 & \\
\hline
\end{tabular}

(2) Basic unit price. First, the calculation results of labor wages and feng shui power budget prices are shown in Figure 5 below. The labor wages are respectively: foreman 7.83 yuan/hour, senior labor 7.36 yuan/hour, intermediate labor 6.18 yuan/hour, junior laborer 4.79 yuan/hour, The wind price is 0.41 yuan $/ \mathrm{m} 3$; the water price is 3.43 yuan $/ \mathrm{m} 3$; self-generated electricity accounts for $100 \%$, and the electricity price is 2.58 yuan $/ \mathrm{kwh}$.

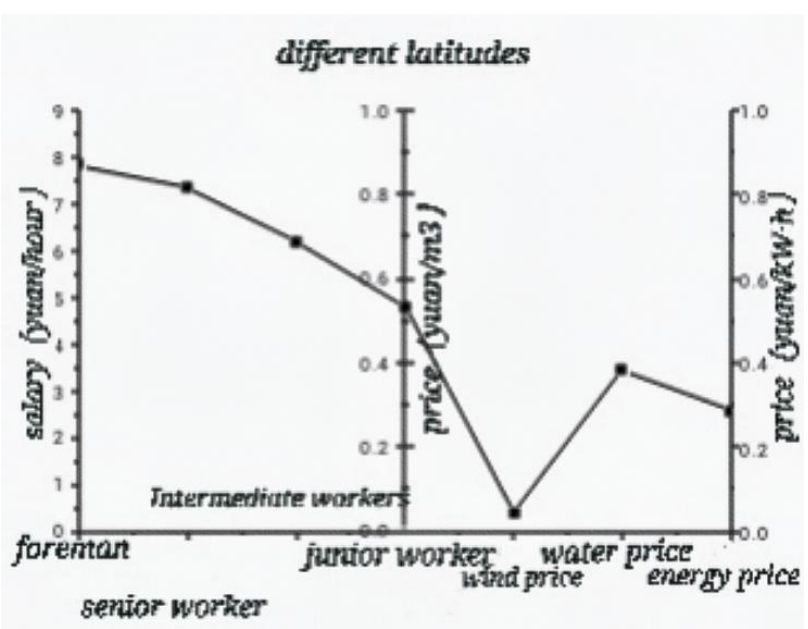

Figure 5 Labor wages and prices of wind, water and electricity

Secondly, the budget prices of main materials are shown in Figure 6 below. The total budget prices of steel bars and sections are $3,843.15$ yuan and $4,09.47$ yuan. The 
total budget price of ordinary Portland cement 42.5 is 418.49 yuan. The total budget price of gasoline and diesel is 6323.96 yuan and 5497.23 yuan. The total budget price of slab lumber and logs is 2473.49 yuan and 2093.32 yuan.

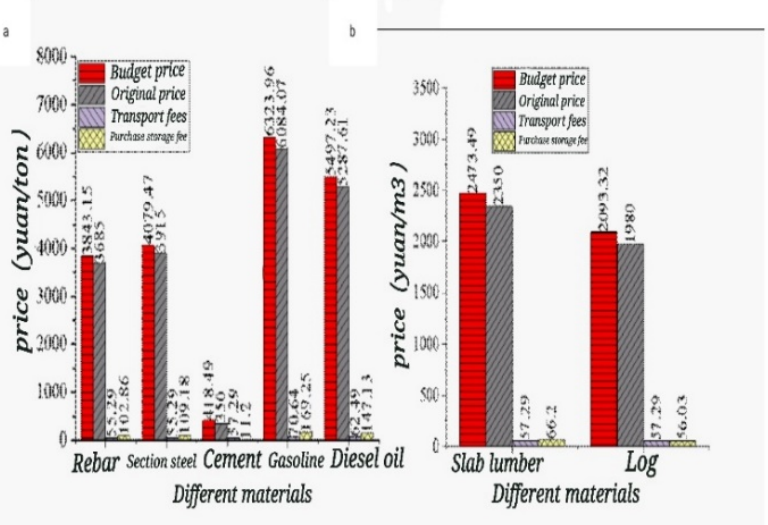

Figure 6 Budget prices of main materials (a: steel and oil b: wood)

Finally, the time cost of the construction machine is shown in Figure 7 below. The total time cost of the $1 \mathrm{~m} 3$ excavator (oil powered), the bulldozer $74 \mathrm{kw}$ and the frog compactor $2.8 \mathrm{kw}$ in the earth-moving machinery is 281.47 yuan/unit hour. The total time cost of the concrete mixer $0.4 \mathrm{~m} 3$, the plug-in vibrator $2.2 \mathrm{kw}$ and the Fengshui gun in the concrete machinery is 143.34 . The total time cost of the $5 \mathrm{t}$ dump truck, $5 \mathrm{t}$ truck, rubber wheeled truck and $5 \mathrm{t}$ winch in the transportation hoisting machinery is 178.54 . The total unit hour rate for the $85 \mathrm{kw}$ diesel generator and $9 \mathrm{~m} 3 / \mathrm{min}$ electric air compressor in the power machinery is 262.03. The total time cost of the submersible pump $2.2 \mathrm{kw}$ and the electric welding machine $30 \mathrm{KVA}$ in other machinery is 94.9 .



Figure 7: Time cost of construction machinery table (1: $1 \mathrm{~m} 3$ excavator (oil driven) 2: bulldozer $74 \mathrm{kw} 3$ : frog compactor 2.8kw 4: concrete mixer $0.4 \mathrm{~m} 3$ 5: plug-in vibrator $2.2 \mathrm{kw} 6$ : Fengshui gun 7: $5 \mathrm{t}$ dump truck 8: Truck 5t 9: Rubber wheel car 10: $5 \mathrm{t}$ winch 11: Diesel generator $85 \mathrm{kw}$ 12: Electric air compressor $9 \mathrm{~m} 3 / \mathrm{min} 13$ : Submersible pump 2.2kw 14: Electric welding machine 30KVA)

(2) Estimated results of segment project investment. The construction project budgetary estimate, construction temporary project budgetary estimate and independent cost estimate are shown in the following Table 8, Table 8 and Table 10. The total cost of underdrain expansion joint treatment is 3.5946 million yuan. The total cost of temporary construction works is 167,000 yuan, including 92,300 yuan for construction of houses and 77,400 yuan for other temporary construction projects. The total independent cost estimate is 603,100 yuan, including survey and design fees of 407,200 yuan, bidding agency fees of 37,600 yuan, engineering construction supervision fees of 141,400 yuan and engineering insurance fees of 16,900 yuan. The total cost of sand removal per $100 \mathrm{~m} 3$ is 8565.65 yuan, the total cost of bricklaying and dismantling per 100 cubic meters is 11841.20 yuan, the total cost of bricklaying per 100 cubic meters of M7.5 cement mortar is 47206.40 yuan, and the total cost of epoxy mortar per cubic meter is 10570.18 yuan.

Table 8 Construction project budgetary estimate

\begin{tabular}{|c|c|c|c|c|c|}
\hline $\begin{array}{c}\text { Serial } \\
\text { number }\end{array}$ & Project or cost name & Unit & Quantity & $\begin{array}{c}\text { Unit Price } \\
\text { (yuan) }\end{array}$ & Price (ten thousand yuan) \\
\hline One & Main Canal Project & & & 359.46 \\
\hline 1 & $\begin{array}{c}\text { Underdrain expansion joint } \\
\text { treatment }\end{array}$ & & 359.46 \\
\hline $\begin{array}{c}15 \text { cm chemically bonded } \\
\text { external TPO waterstop }\end{array}$ & $\begin{array}{c}\text { Sediment removal in } \\
\text { culvert }\end{array}$ & $\mathrm{m} 3$ & 9966.44 & 334.73 & 359.46 \\
\hline & $\begin{array}{c}\text { Manual M7.5 bricklaying } \\
\text { and plugging (including } \\
\text { demolition) }\end{array}$ & $\mathrm{m} 3$ & 36.86 & 590.47 & 21.59 \\
\hline & \begin{tabular}{c} 
Epoxy mortar repair \\
\hline
\end{tabular} & $\mathrm{m}$ & 1.97 & 10570.18 & 2.18 \\
\hline
\end{tabular}


Table 9 Estimated budget of temporary construction works

\begin{tabular}{|c|c|c|c|c|c|}
\hline Serial number & Project or cost name & Unit & Quantity & $\begin{array}{c}\text { Unit Price } \\
\text { (yuan) }\end{array}$ & $\begin{array}{c}\text { Price (ten } \\
\text { thousand } \\
\text { yuan) }\end{array}$ \\
\hline & Construction temporary works & & & & 16.97 \\
\hline One & Construction house construction project & & & & 9.23 \\
\hline & Office, living and cultural welfare buildings & $\mathrm{m} 2$ & 190 & 350 & 6.65 \\
\hline & Construction warehouse & $\mathrm{m} 2$ & 129 & 200 & 2.58 \\
\hline Two & Other temporary construction works & ten thousand yuan & 368.69 & $2.10 \%$ & 7.74 \\
\hline
\end{tabular}

Table 10 Independent cost estimate

\begin{tabular}{|c|c|c|c|c|c|}
\hline $\begin{array}{c}\text { Serial } \\
\text { number }\end{array}$ & Project or cost name & Unit & Quantity & $\begin{array}{c}\text { Unit Price } \\
\text { (yuan) }\end{array}$ & Price (ten thousand yuan) \\
\hline One & Survey and design fee & $\begin{array}{c}\text { ten thousand } \\
\text { yuan }\end{array}$ & & & 60.31 \\
\hline Two & Tender agency fee & $\begin{array}{c}\text { ten thousand } \\
\text { yuan }\end{array}$ & & & 40.72 \\
\hline Three & $\begin{array}{c}\text { Project construction } \\
\text { supervision fee }\end{array}$ & $\begin{array}{c}\text { ten thousand } \\
\text { yuan }\end{array}$ & & 3.76 \\
\hline Four & Other & $\begin{array}{c}\text { Engineering insurance } \\
\text { ten thousand } \\
\text { yuan }\end{array}$ & 376.43 & $0.45 \%$ & 14.14 \\
\hline
\end{tabular}

\section{Conclusion}

This research is based on the theoretical basis of cost management, taking the reinforcement treatment of the expansion joints of the concealed channels in the main canal project of the first phase of the water diversion water supply as a research case. In the cost management of the project, it is necessary to focus on the expansion joints that have problems, and the design guide The processing range and length of the underdrain expansion joints of the high collapsibility loess foundation in the main trunk canal project of Tao Water Supply. According to the characteristics of the expansion joint filling materials, the bonded external TPO waterstop and PTN petroleum asphalt polyurethane joint materials are selected as the joint materials Expansion joint repair materials, and a general estimate of the project, including the estimate of each part, so as to ensure the efficient operation of project operation management. This research also has certain shortcomings. It is not obvious for the information elements involved in operation management. In the later research, it will expand the scope of informationization.

\section{References}

1. Wang J, Zhao H, Y Ye. Smart water grid project:the engine driving China's water management modernization strategy. Shuili Xuebao/Journal of Hydraulic Engineering, 2018, 49(9), pp. 1148-1157.
2. Zhujun Peng. Analysis of Influencing Factors of Water Conservancy Project Investment and Research on Management Methods. Agricultural Technology Service, 2016 (9th issue), pp. 145-145.

3. Wang Shunli. Research on Cost Management and Control of Farmland Water Conservancy Projects. Chinese and Foreign Entrepreneurs, 2020, No.670(08), pp. 62-62.

4. Huang Jian. Research on Phased Measures for Investment Control of Water Conservancy Project Construction. Hebei Water Resources, 2020, No.308(10), pp. 32-33.

5. Zhao Lei. Analysis of Construction Cost Control of Water Conservancy Projects. Global Market Information Report, 2017, 000(047), pp. 50-50.

6. Ma Ji. Analysis on the application of target cost management in water conservancy engineering construction projects. Science and Technology Pioneering Monthly, 2016, 29(023), pp. 90-91.

7. Yao Yuan. Discussion on several key issues in water conservancy project construction management. Urban construction theory research: electronic edition, 2016, 000(010), pp. 5247-5247.

8. Cui Jindong, Zheng Que, Zhou Niancheng, et al. Research on cost management methods of power grid projects in smart economic park based on big data. Science and Technology Management Research, 2018, v.38; No.400(06), pp. 173-181.

9. Li Chunyan. Analysis of common problems and 
solutions in water conservancy project bidding. Green building materials, 2019, 143(01), pp. 225-225.

10. Tang Min, Yao Ying. The main work and results of water conservancy project construction and management. Henan Agriculture, 2017, 000(023), pp. $42-42$. 